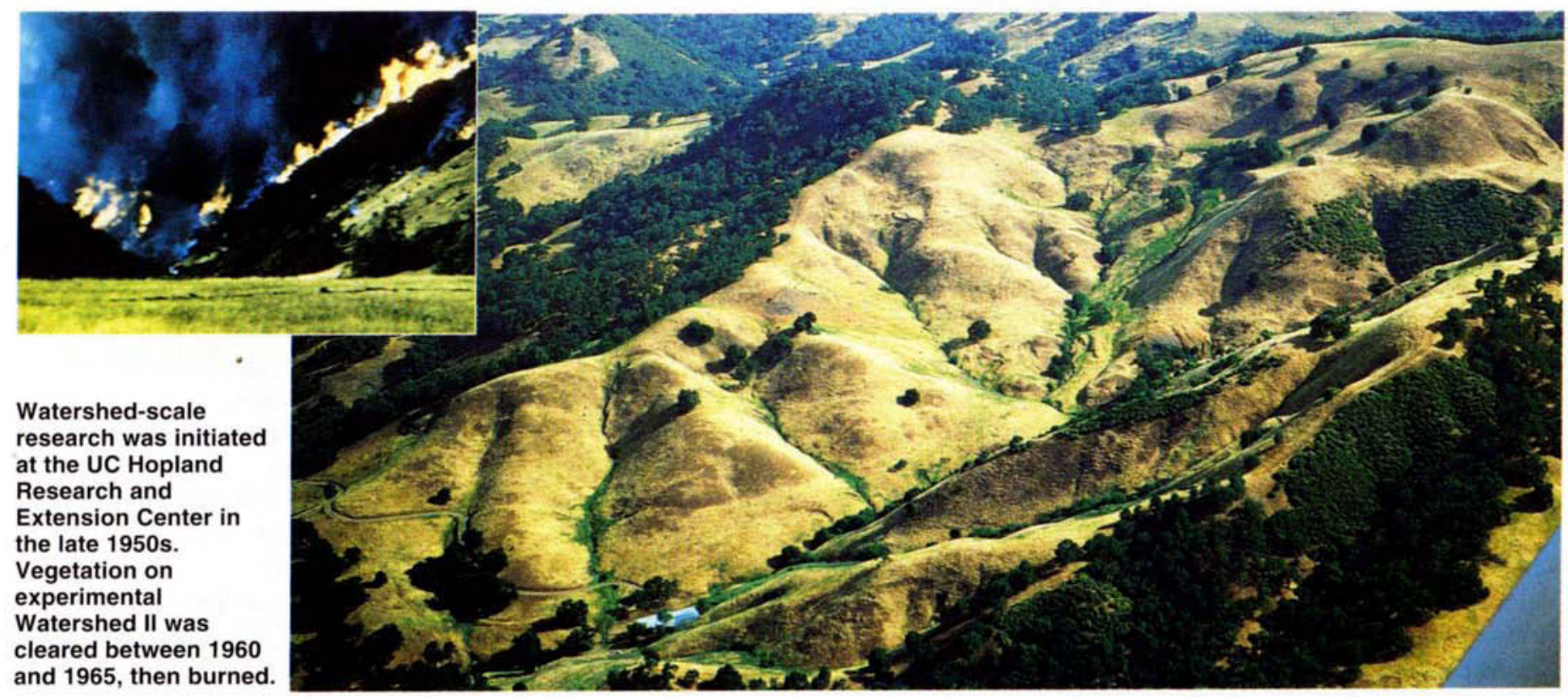

\title{
Watershed research examines rangeland management effects on water quality
}

\author{
Randy A. Dahlgren $\square$ Kenneth W. Tate $\square$ David J. Lewis \\ Edward R. Atwill \ John M. Harper \ Barbara H. Allen-Diaz
}

Oak- and annual grassdominated rangelands in California occupy 7.4 million acres, often occurring at the state's urban, wildland and agricultural interface. Rapidly changing land uses in these ecosystems have watershedscale impacts that are the subject of intense debate among policy-makers, environmentalists and landowners. Watershed research conducted at the UC Hopland Research and Extension Center (HREC) between the 1950s and 1980s provided valuable information for predicting the effects of watershed management activities - such as converting oak and chaparral to grasslands - on water quantity and quality, slope stability and erosion. The research illustrated that conversion from woodland to grassland significantly impacts the hydrology and sediment dynamics of watersheds, suggesting that land-use changes such as vineyards and urban expansion must be evaluated carefully. Preliminary data from a new series of watershed studies initiated at HREC in 1998 indicate that livestock grazing does not significantly increase nutrient and sediment levels in stream water, but that current fecal coliform standards may be exceeded during storm events.

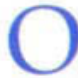
ak woodlands at the urbanwildland-agricultural interface are being changed by conversion to vineyards, removal of livestock and increased fire-fuel loads. At the same time, vegetation management tools such as oak tree harvest, grazing and prescribed fire allow managers to maintain economically feasible agricultural enterprises, preserve open space, improve wildlife habitat and control weed infestations. However, there is a paucity of information on the watershed-scale impacts of these management practices and land-use changes. Recent events that have also fueled public concern include the addition of aquatic species to the federal endangered species list, development and enforcement of federal waterquality standards called total maximum daily loads (TMDLs), litigation concerning the impacts of grazing on
\end{abstract}




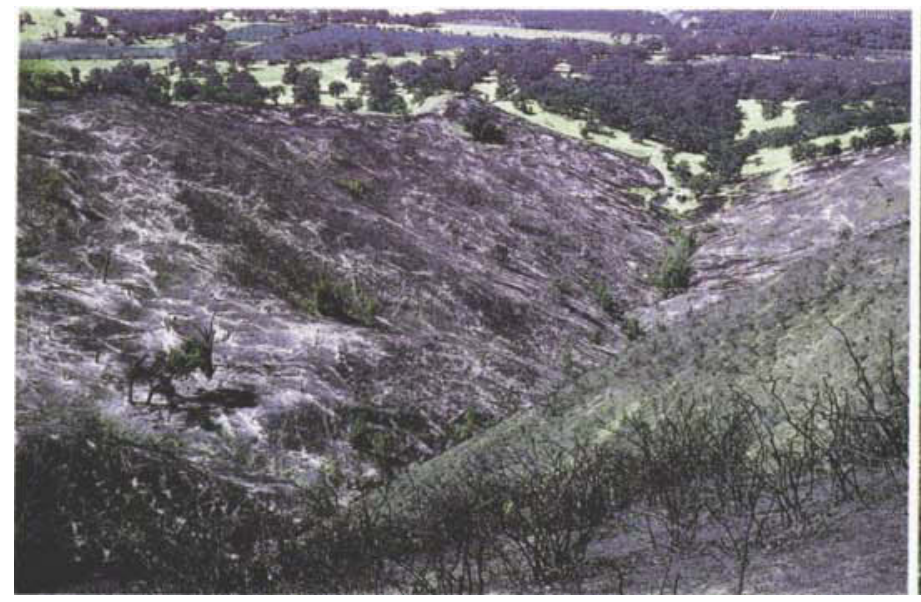

Between the late 1950 s and early 1980 s, watershed research at HREC focused on the impacts oak woodland-to-grassland conversion on water quantity, slope stability and erosion.

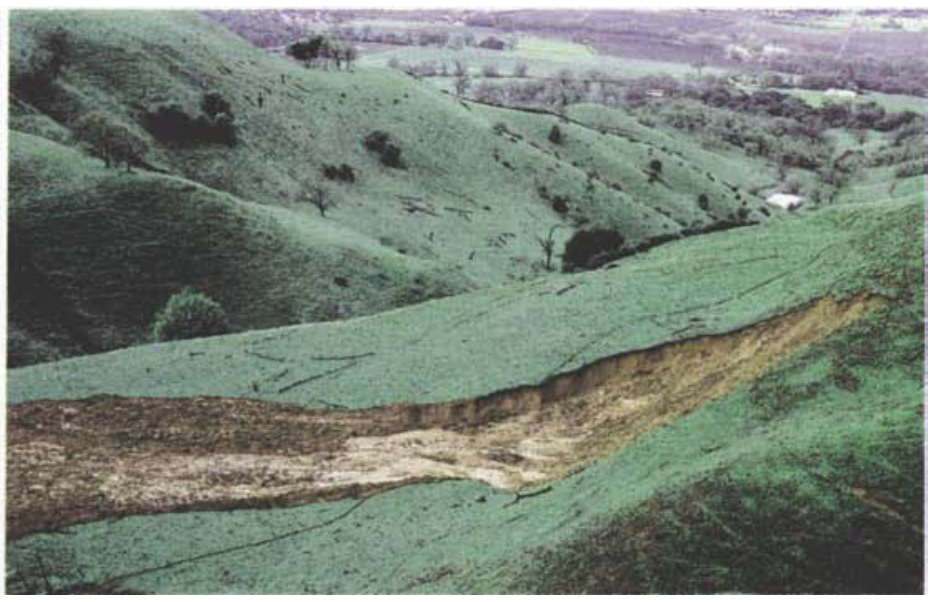

Watershed II was cleared in 1965, left; 20 years later, a large soil slip occurred following February rains, right. municipal drinking-water quality, and costly wildfires due, in part, to unmanaged vegetation.

Watershed-scale studies, such as those conducted at the UC Hopland Research and Extension Center (HREC) in southern Mendocino County, are critical for evaluating the effects of watershed management practices. Properly extended to land management, regulatory and conservation groups, the results of watershed studies can assist in informed decision-making, enhancement of watersheds and protection of water quality.

\section{Experimental watersheds}

Beginning in the early 1950s, a series of watershed studies has been undertaken on experimental watersheds at HREC, ranging in size from 30 to 210 acres. All have relatively steep slopes, from $20 \%$ to $60 \%$. Native vegetation on six lower-elevation watersheds (500 to 1,000 feet) is dominated by oak woodland and annual grassland. In contrast, vegetation in three higher-elevation watersheds $(1,600$ to 2,000 feet) is mostly chaparral.

The climate at Hopland is Mediterranean, with a mean annual precipitation of 37 inches and mean annual temperature of $57^{\circ} \mathrm{F}$. Soils in the watersheds are moderately developed and shallow, rarely exceeding 3 to 4 feet deep. The underlying geological material is sedimentary rock of the Franciscan formation, consisting of sandstone and shale with interspersed basalt and serpentine.

Vegetation affects the hydrologic cycle primarily through evapotranspiration and the interception of water. Both processes are a direct function of the type and density of vegetation present in the watershed. Native vegetation is being lost on California watersheds due to housing development, conversion to agricultural crops (especially vineyards), forage production enhancement, sudden oak death syndrome, and the death of oaks in wildfires.

Research conducted by Robert Burgy (Professor Emeritus in the UC Davis Department of Land, Air and Water Resources) and co-workers on HREC Watersheds I and II - from 1952 until the early 1980s - provided important information for predicting the effects of current oak-woodland vegetation conversions on watershedscale water yields, soil stability and erosion. For the purposes of this paper, we collected information concerning these studies from a series of publications and reports. The information reported below is a synthesis of these various sources and is based on data collected from Watersheds I and II.

In 1952, 63 acres at HREC Watershed I and 210 acres at Watershed II were fitted with instruments, including precipitation gauges, stream runoff measuring stations and debris basins for sediment transport measure- ments. Both watersheds were located at lower elevations with typical oakwoodland vegetation. After 4 to 7 years of baseline data collection, vegetation in Watershed I was mechanically removed in 1956, followed by burning of woody materials, treatment of stumps with the herbicide 2,4-D (2,4-dichlorophenoxyacetic acid) and seeding of a grass-legume mixture. Between 1960 and 1965, vegetation in Watershed II was killed with 2,4-D. Dead trees were left in place. In 1965 , the watershed was burned and reseeded with forage species. Vegetation, stream flow and sediment data were collected from both Watershed I and II for over a decade following vegetation conversion on each watershed, respectively.

\section{Vegetation and water yields}

Results of this research showed that approximately 6 to 10 inches of precipitation are required to initiate stream flow on a watershed. Once the water-holding capacity of the soil was filled, additional precipitation generated stream flow. Removal of woody vegetation with deep rooting systems reduces the amount of water extracted from the lower soil profile. Any residual soil water storage carried forward to the next water year (Oct. 1 through Sept. 30) reduced the amount of priming (the amount of rainfall required to initiate stream flow) necessary to generate stream flow in the 

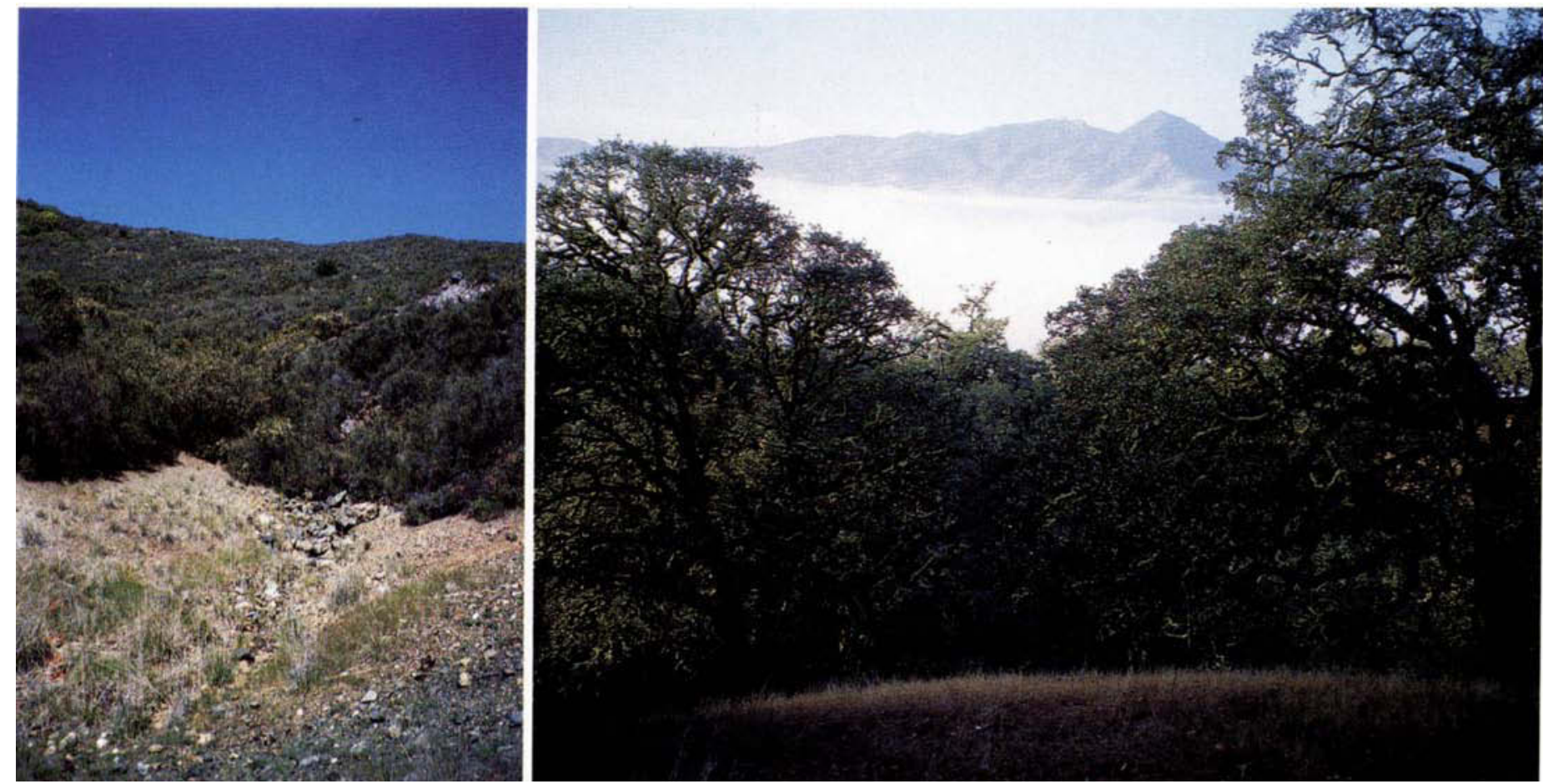

In the late 1990s, scientists launched a new series of studies on seven experimental watersheds at Hopland. Chaparral, left, is the dominant vegetation type on higher elevation $(1,600$ to 2,000 feet) watersheds, while oak woodlands, right, are typical at the lower elevations (500 to 1,000 feet).

next water year, resulting in greater water yields.

Furthermore, Burgy and colleagues found that converting woodlands to grass vegetation retarded runoff during storms, and resulted in nearly a doubling in the length of storm hydrographs from both watersheds. (Hydrographs plot the flow or discharge of a waterway through time.) After conversion to grass vegetation, peak runoff rates were reduced by about $25 \%$ compared to pretreatment storms (Burgy 1968). This response is different from that realized in other studies conducted in other woodland and forest systems of the hydrological consequences of conversion from woody to grass vegetation (Bosch and Hewlett 1982). The longer hydrograph responses indicated a prolongation of runoff and a greater contribution of water from subsurface flows. These changes resulted from an increase in grass cover (Murphy 1976) that retarded overland flow and permitted more opportunities for infiltration (Burgy 1968). Reduced evapotranspiration following the removal of deeply rooted trees also resulted in a long- term increase in runoff and an extension of base flow through the dry season. After the vegetation was converted, intermittent streams became perennial on HREC Watersheds I and II.

Grasses intercepted far less rainwater than trees and shrubs, increasing the amount of rainfall reaching the soil surface. While brush and oak trees intercept about $10 \%$ to $25 \%$ of the precipitation that falls, interception by grasses was found to be negligible (Burgy and Pomeroy 1958). Stream discharges increased by an average of $60 \%$ after the vegetation conversion, with an increase in runoff of about 4 inches per year (Burgy and Papazifiriou 1971b).

In addition, annual runoff was strongly correlated with annual precipitation on the HREC experimental watersheds. While there was a high correlation between runoff and total precipitation, the seasonal distribution of precipitation was an important factor affecting total annual water yields. March was the critical month in the runoff process. During the seasonal runoff period leading up to March, there was a definite increase of water yield in the watersheds converted to grass vegetation. During March, the effect of treatment was variable, sometimes positive and sometimes negative (Burgy and Papazifiriou 1971b).

This behavior may be explained by examining the growth patterns of grasses and oak vegetation. At HREC, high temperatures in March promote the growth of grasses, resulting in increased evapotranspiration. In contrast, deciduous oak trees are not in full leaf during March, resulting in less water loss to interception and evapotranspiration. Rainfall in April and May often produces no runoff due to higher evapotranspiration demands, especially after deciduous trees leaf out.

These experimental results have important ramifications for vegetation and land-use conversion throughout the California Coast Range. Increased peak flows during storms and reduced flood hazards are among the consequences of converting woody vegetation to grasslands. This is significant, for example, in the development of hydrologic models simulating flood 

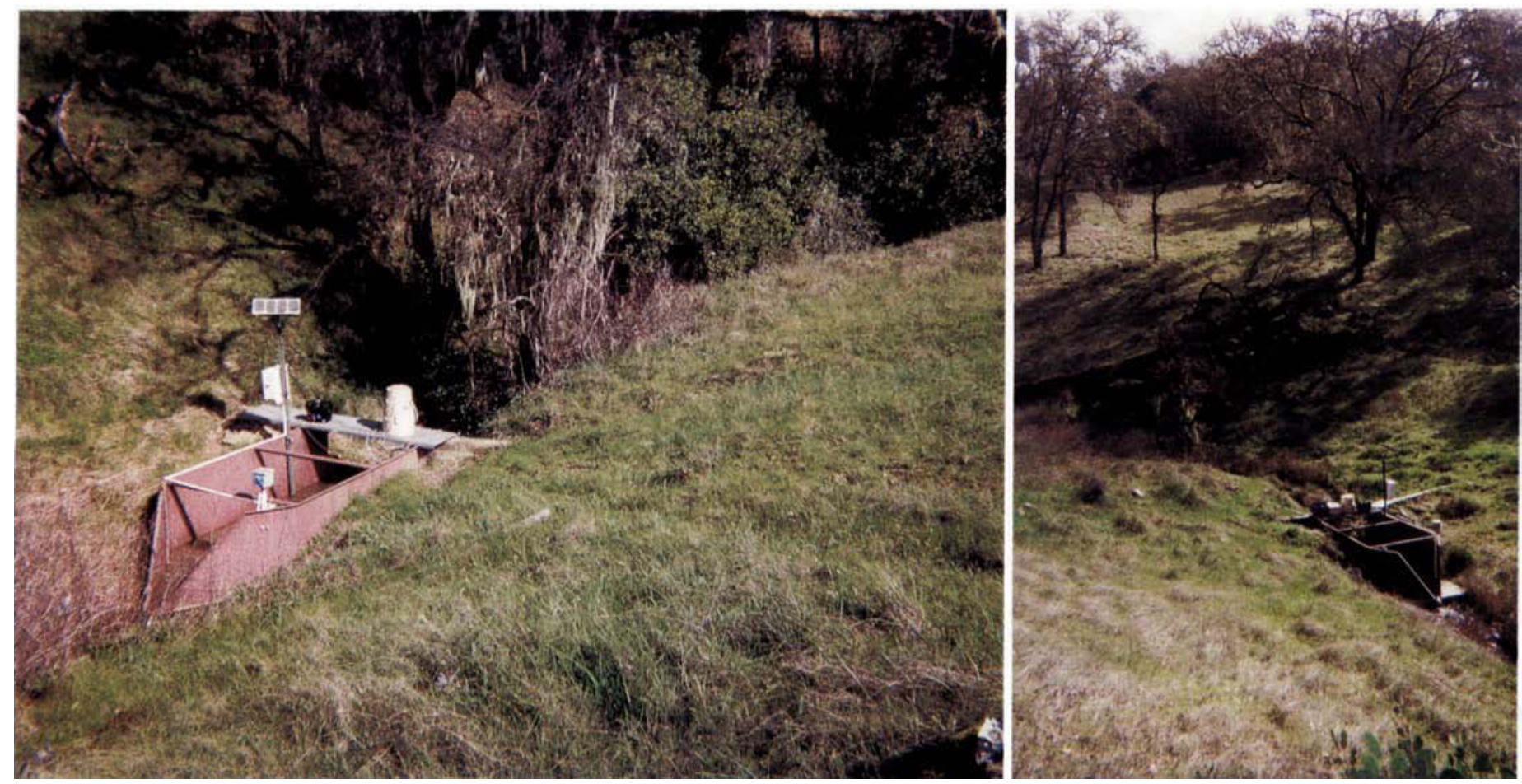

Stream flow and water-quality sampling equipment are located at the outlet of each experimental watershed. In coming years, studies will focus on the roles that grazing and fire management play in plant communities, hydrology and water quality.

events in the Russian River watershed. The data from Watersheds I and II further suggest that agricultural production practices in this region should maintain soil surface cover to enhance water infiltration and reduce surface runoff. Low ground cover leads to increased annual water yields, and especially increased summer/fall base flows. These can have benefits for anadromous fish species and the health and integrity of the aquatic ecosystem. Similarly, the conversion of ephemeral to perennial streams in upland watersheds will improve wildlife habitat by providing a summer source of water. However, these stream flowrelated benefits came with associated, and significant, erosion problems.

\section{Soil stability and erosion}

The coastal mountains of Northern California have some of the highest sedimentation rates in the world. Vegetation types and amounts have a tremendous influence on slope stability and erosion. Plant and litter cover protect soil aggregates from destruction by the impact of rain and slow overland flows, thereby providing greater opportunity for water infiltration. The removal of deeply rooted vegetation, such as oaks and brush, reduces the mechanical reinforcement of the soil profile on hill slopes provided by the root system. Fire also influences erosion by reducing infiltration rates, contributing to soil hydrophobicity (water repellency) and removing surface cover. Infiltration reduction is usually proportional to the severity of burning.

In the years following the removal of woody vegetation described above on Watershed II, sedimentation increased from about 1.9 to 19.1 tons per acre per year. Erosion rates increased substantially 3 to 4 years following vegetation conversion due to an increase in mass-wasting events associated with the decay of tree and shrub roots (Murphy 1976; Burgy and Papazifiriou 1971a). (Mass wasting is the "mass" erosion of hill-slope soils.)

While there were no massive soil movements prior to the removal of woody vegetation from Watershed II, there was a total of 61 soil slips in the subsequent 10 years (Burgy and Papazifiriou 1971a). Two types of mass wasting were identified: slippage of slopes along a failure plane, and mud flows due to soil liquefaction. The majority of mass-wasting events occurred near stream channels on Watershed II, with stream scouring and bank cutting preceding each event. The mass-wasting events identified by HREC researchers on Watershed II occurred on slopes with minimum gradients of $45 \%$. The number of events per year was directly proportional to the amount of annual rainfall. Vegetation conversion from woody plants to grasses reduces slope stability by removing the soil reinforcement provided by root systems and increasing soil-moisture content, causing soil strength to decrease.

The Russian River and several other Coast Range rivers are impaired by suspended sediments and are listed for the development of total maximum daily load (TMDL) regulations under the federal Clean Water Act. Results from HREC watershed studies conducted by Burgy and co-workers from the 1950 s to the early 1980 s demonstrate the potential for high soilerosion rates following watershed dis- 


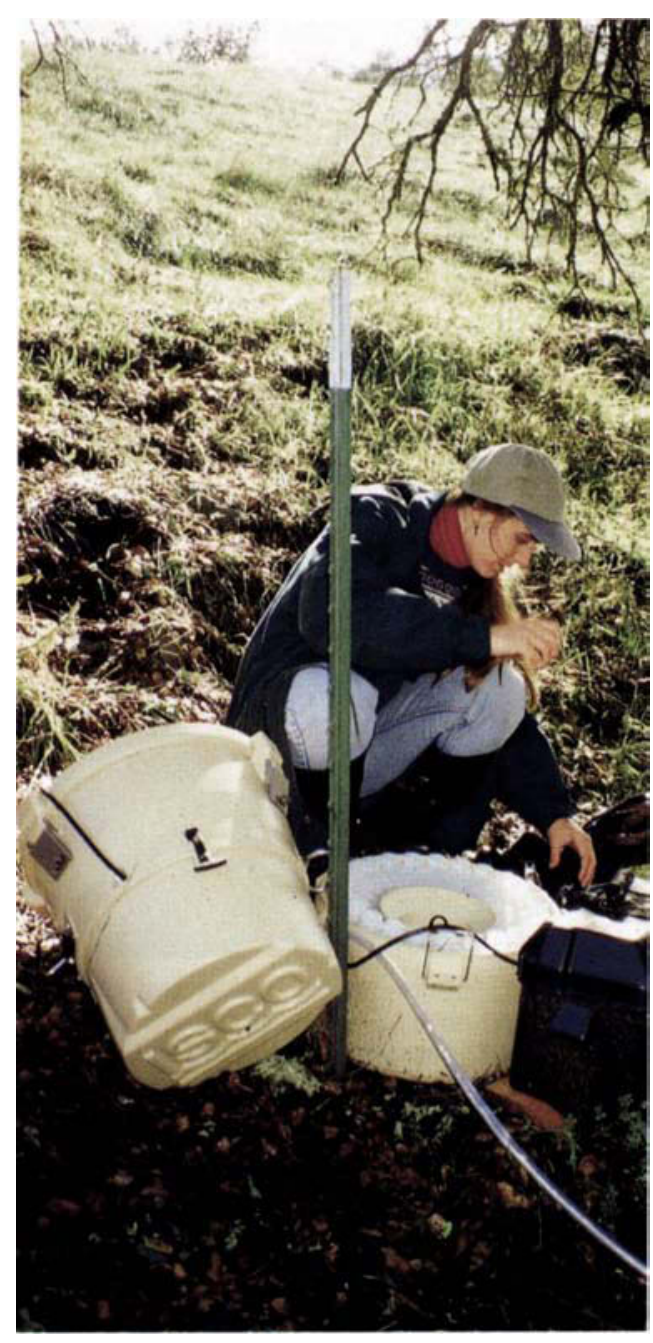

Preliminary data indicate that current land use and management practices are not impairing water quality on the seven experimental watersheds. Julie Smith monitors automatic water samplers.

turbances that remove woody vegetation and reduce soil cover. Land-use conversions, such as rangeland to vineyard, must assure adequate soil cover to minimize erosion and address factors contributing to mass wasting. Burgy's HREC studies indicate that slopes greater than $45 \%$ are highly susceptible to mass wasting, especially channels near streams. These experimental results also suggest that an adequate buffer strip of woody vegetation should be maintained adjacent to stream channels to attenuate mass wasting.

\section{Fire and grazing management}

In 1998, the UC Rangeland Watershed Program began a long-term, watershed-scale examination of fire- and grazing-management effects on plant community dynamics, hydrology, nutrient cycling and water quality on seven new, long-term experimental watersheds at HREC.

Both grazing and fire are increasingly being used to control the spread of invasive species (see p. 47) and reduce fuel loads and the potential for catastrophic fires. However, the effects of these management practices on watershed processes have not been thoroughly documented.

Due to HREC's long history of watershed research and its representation of North Coast oak woodlands, it is an ideal location for continued watershed studies. New research will specifically address water quality issues, adding nutrients and pathogens to the suite of pollutants examined in the past by Burgy and co-workers. For this current work, seven new experimental watersheds have been developed.

Following a paired-watershed study design, we have added instruments that monitor stream flow and water quality in four oak woodlandgrassland sites and three chaparral watersheds. We collected 3 years of baseline data for use in calibrating the two sets of watersheds. These data show that the four oak woodlandgrassland sites can be treated as pairs and that the three chaparral watersheds can be treated as pairs with respect to hydrology and nutrient transport, allowing us to test for treatment effects within both vegetation types. Over the next 3 years, we will implement grazing and prescribed burning treatments and monitor the effects.

Baseline monitoring of the four oak woodland experimental watersheds (A, B, C and D) commenced in 1998. Watersheds A (29.1 acres) and B
(22.3 acres) have historically been, and are currently used for light-to-moderate sheep grazing, primarily from January to March. Watersheds C (56 acres) and D (19.7 acres) have been excluded from livestock grazing since 1955. Baseline monitoring of the three chaparral watersheds $(E=21.4$ acres, $\mathrm{F}=20.0$ acres, and $\mathrm{G}=31.7$ acres) began in 1999. All three watersheds have complete chaparral coverage and are part of a pasture grazed by sheep.

Stream flow is monitored at flumes installed at the outlet of each watershed. Stream flow is measured and recorded at 15-minute intervals using an electronic-stage sensor and recorded with a data logger. Stream water samples are collected at 1-to-2-hour intervals during storms, using automatic-pump samplers, and every 3 to 4 days during base flow, using grab samples.

In addition to the seven long-term experimental watersheds recently established at HREC, since 1998 we have been monitoring water quality and stream flow on Parson's Creek, a tributary of the Russian River, where it flows through HREC. The Parson's Creek watershed is approximately 5,500 acres and represents the next step up in scale from earlier experimental watersheds. About one-half of the Parson's Creek watershed is contained within HREC. The data collected from Parson's Creek will allow us to put the results from our seven small watersheds into context with regard to watershed scale and the region's ambient grazing management. Vegetation within Parson's Creek watershed is composed of oak woodland and annual grassland in the lower elevations, with chaparral in the higher elevations.

\begin{tabular}{|c|c|c|c|c|c|}
\hline \multicolumn{6}{|c|}{$\begin{array}{l}\text { TABLE 1. Stream runoff and runoff-to-rainfall ratios for the } 1999-2000 \text { water year } \\
\text { in three representative HREC research watersheds }\end{array}$} \\
\hline Watershed & Vegetation & Land use & Area (acres) & Runoff (inches) & Runoff/rainfall \\
\hline & & & ac. & & \\
\hline B & Oak woodland & Grazed & 22 & 7.1 & 0.20 \\
\hline C & Oak woodland & Nongrazed & 56 & 4.6 & 0.13 \\
\hline G & Chaparral & Grazed & 32 & 5.5 & 0.15 \\
\hline
\end{tabular}



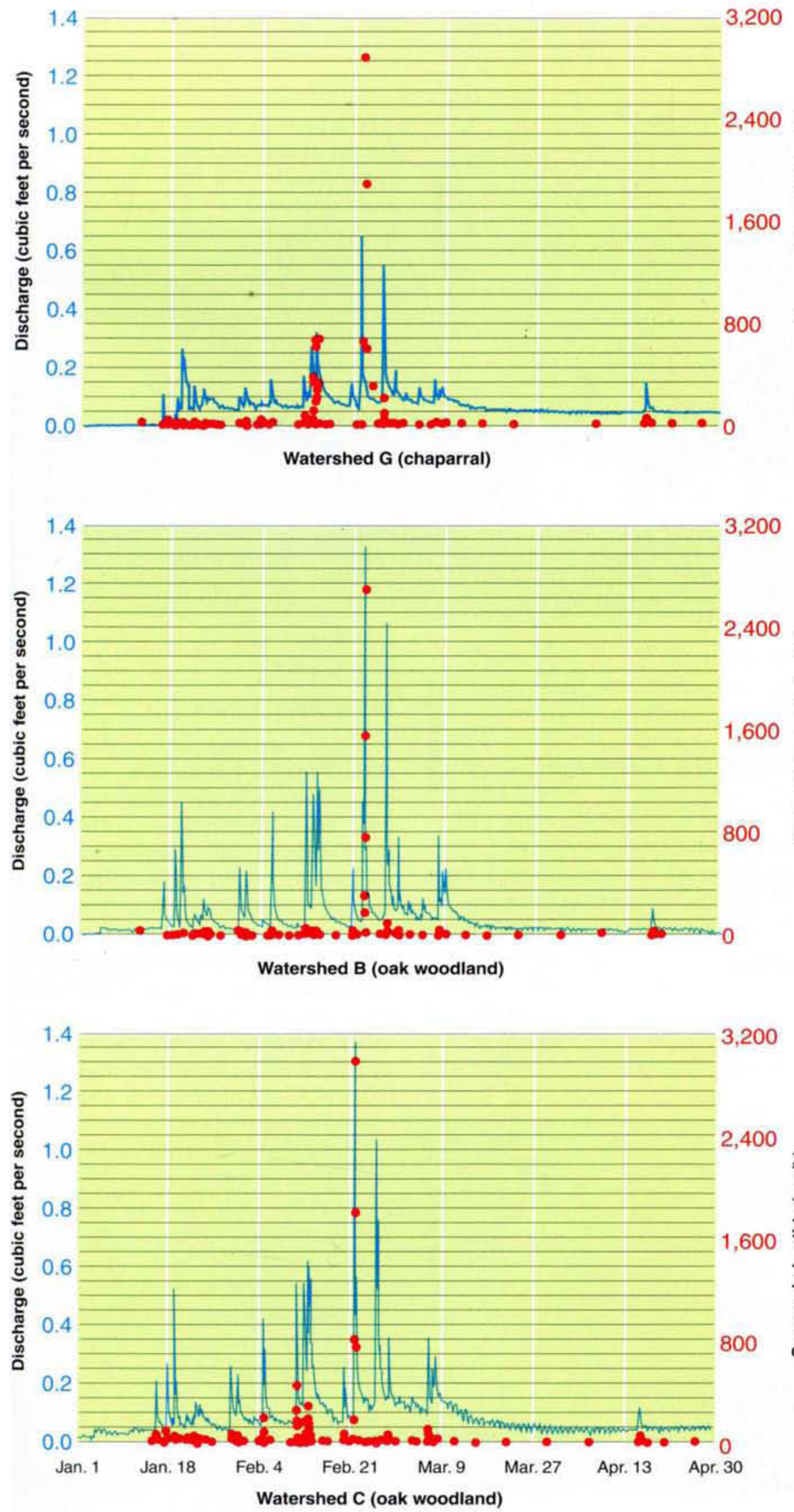

Fig. 1. Stream flow (line) and suspended solids concentrations (dots) from HREC Watersheds B, C and G for the 1999-2000 water year.
Parson's Creek flows intermittently, with little to no mid- and late summer surface flow. Land use on the watershed is dominated by grazing with associated ranch-road systems and habitation. We measure Parson's Creek stream flow using the area-velocity method. Grab water samples are collected intensively during storms, and periodically during base flow conditions.

\section{Water quality measurements}

Our baseline monitoring provides timely insight into the quality of water coming from North Coast rangeland watersheds. All water samples are analyzed for major cations and anions, nutrients and suspended solids. Combining nutrient concentration data (milligram per liter; $\mathrm{mg} / \mathrm{L}$ ) and water flow data $(\mathrm{L})$ allows us to calculate annual fluxes (1.0 pound/acre/year; 0.89 kilogram/hectare/year) from each watershed. We also began analysis for selected fecal indicators and pathogens, such as fecal coliforms and $E$. coli, in Parson's Creek during the 2000-2001 water year.

There were 35.9 inches (mean annual precipitation [MAP] $=36.7$ inches) of precipitation at HREC during the 1999-2000 water year, with the majority of precipitation occurring in February. The watersheds were not fully primed until February with 8 to 10 inches of rain, which produced significant stream flows. All three watersheds display a similar series of storm hydrographs, the magnitude of the peaks being a function of precipitation and watershed area (fig. 1). Runoff from three representative watersheds (B, C and G) ranged from 4.6 to 7.1 inches with rainfall-to-runoff ratios of 0.13 to 0.20 (table 1 ). Suspended solids concentrations were generally low, except during two storms in mid- to late February (fig. 1). While the chaparral watershed had higher suspended solids concentrations, the total sediment flux (table 2) was not appreciably higher than the grazed oak woodland, due to lower runoff volumes (table 1). 


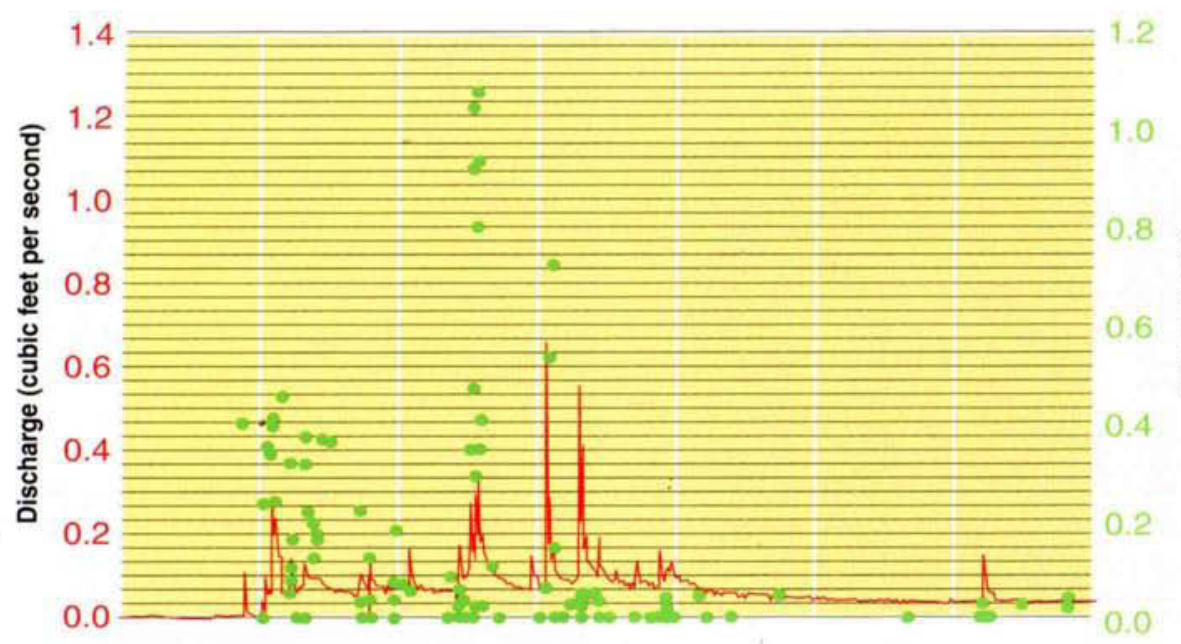

Watershed G (chaparral)

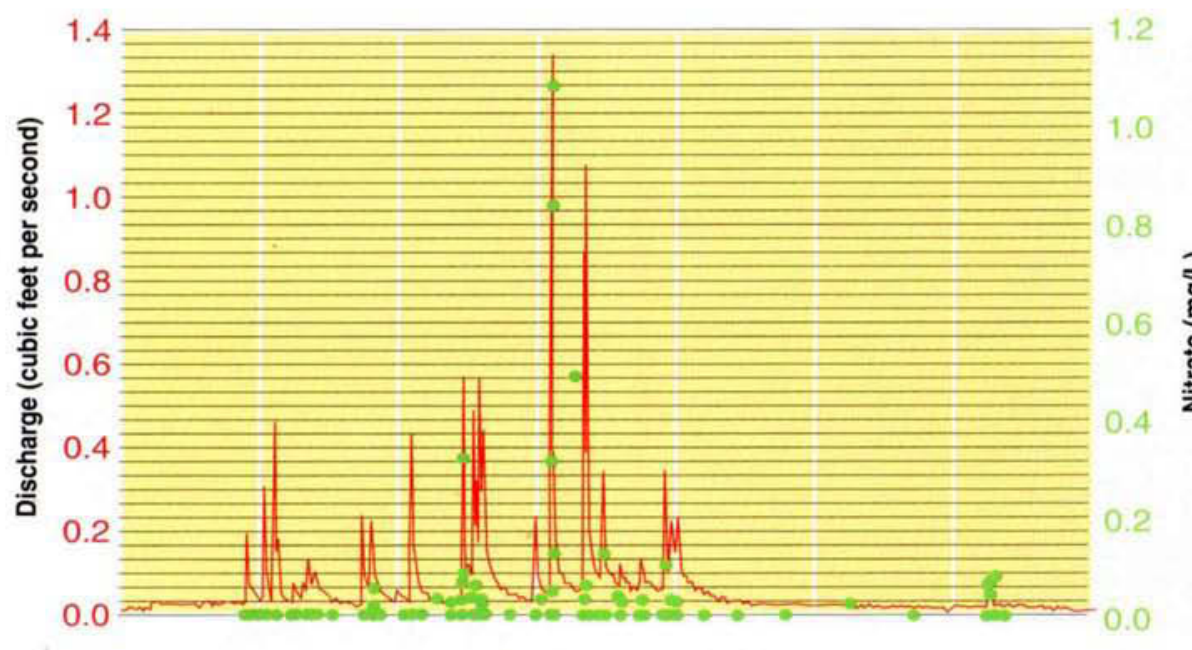

Watershed B (oak woodland)

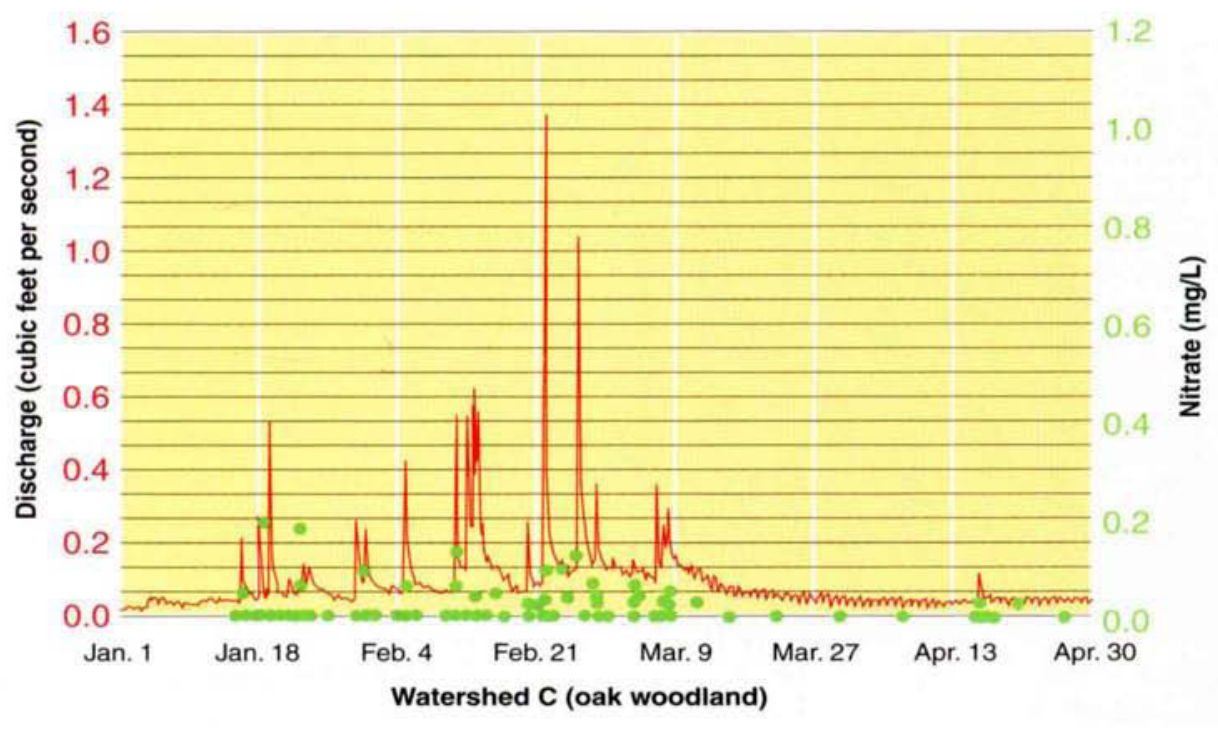

Fig. 2. Stream flow (Jine) and nitrate concentrations (dots) from HREC Watersheds B, C and $G$ for the 1999-2000 water year.
The average stream-water $\mathrm{pH}$ was similar among all three watersheds: Watershed $B=7.4$, Watershed $C=7.6$ and Watershed $G=7.8$. Concentrations of dissolved constituents were dominated by calcium, magnesium and bicarbonate (table 2). Streamwater nitrate concentrations were generally less than 1 milligram per liter (U.S. Environmental Protection Agency's drinking water standard is 45 milligram per liter) and displayed distinctly higher concentrations in the chaparral Watershed $G$ as compared to the oak woodland Watersheds B and $C$ (fig. 2). Mean flow-weighted concentrations and annual fluxes for the nutrients of greatest concern in water quality (nitrate, ammonium and phosphate) were very low for all watersheds (table 2).

\section{Watershed trends}

These nutrient levels indicate that current land use and management practices are not impairing water quality in these watersheds at HREC. Most other water quality components measured in this study had similar concentrations among watersheds, with the exception of somewhat lower sulfate and higher magnesium concentrations in the chaparral Watershed G. Besides land use and management practices, other watershed characteristics, such as vegetation, soils and geology, may contribute to differences in water chemistry among our experimental watersheds. Future studies that implement grazing and prescribed burning treatments will allow us to test the specific effects of these treatments on water quality.

The potential for non-point-source microbial contamination of surface waters from livestock has emerged as a major human health concern. Firstyear results of selected microbial parameters in Parson's Creek show a wide range of fecal coliform ( 8 to 12,200 colony forming units [cfu] per 100 milliliter) and $E$. coli ( 3 to 80 cfu per 100 milliliter) concentrations over the water year. Fecal coliforms are of- 


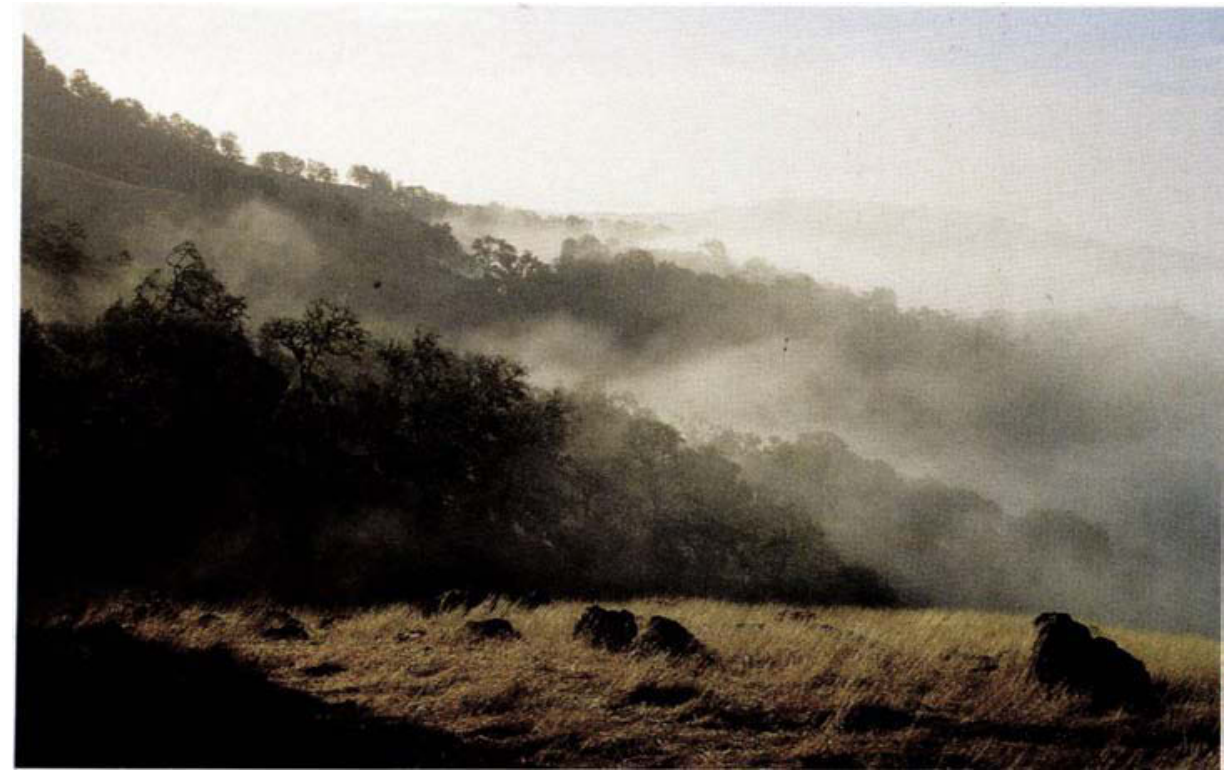

Long-term, watershed-scale studies can provide critical information for the development of best management practices, as well as total maximum daily loads (TMDLs) and water-quality regulations for North Coast rangelands.

ten used as water quality standard for fecal-borne pathogens. Typical regulatory criteria for fecal coliforms across California range from 20 to $200 \mathrm{cfu}$ per 100 milliliter for drinking water and bodily contact. So far, microbial pathogen concentrations show a strong positive relationship with stream flow volume and suspended solids concentrations, suggesting that surface runoff during storms is an important hydrologic pathway trans- porting microbial pathogens to stream waters.

Fifty years of watershed research at HREC have provided valuable information concerning the effects of range management practices on water yield, water quality, slope stability and erosion. This research is critical for developing and validating best management practices and putting water quality regulations, such as TMDLs, into context for California rangelands.
R.A. Dahlgren is Professor, Soils and Biogeochemistry Program, UC Davis; K.W. Tate is Rangeland Watershed Specialist, Department of Agronomy and Range Science, UC Davis; D.J. Lewis is Watershed Management Advisor, UC Cooperative Extension (UCCE), Sonoma County; E.R. Atwill is Environmental Animal Health Specialist, School of Veterinary Medicine, UC Davis; J.M. Harper is Livestock and Natural Resources Advisor, UCCE Mendocino County; and B.H. Allen-Diaz is Professor and Associate Dean, College of Natural Resources, UC Berkeley.

\section{References}

Bosch JM, Hewlett JD. 1982. A review of catchment experiments to determine the effect of vegetation changes on water yield and evapotranspiration. J Hydrol 55:2-23.

Burgy RH. 1968. Hydrological Studies and Watershed Management on Brushlands. Annu Rep No 8 to Calif Dept Water Resources and UC Water Resources Ctr. 22p.

Burgy RH, Papazifiriou ZG. 1971a. Effects of vegetation management on slope stability, Hopland Experimental Watershed II at Hopland Field Sta. Abstr for Water Resources Ctr Adv Council Meeting. 10 p.

Burgy RH, Papazifiriou ZG. 1971b. Vegetative management and water yield relationships. Proc. 3rd Intern Seminar for Hydrology Professors. Purdue Univ. p 315-31.

Burgy RH, Pomeroy CR. 1958.

Interception losses in grassy vegetation. Trans Amer Geophysical Union 39:1095-100.

Murphy AH. 1976. Watershed management increases rangeland productivity. Cal Ag 30(7):16-21.

\begin{tabular}{|c|c|c|c|c|c|c|c|c|c|c|c|}
\hline \multicolumn{12}{|c|}{$\begin{array}{l}\text { TABLE 2. Mean flow-weighted concentration and flux } \\
\text { on HREC watersheds (B, C, G) for } 1999-2000 \text { water year* }\end{array}$} \\
\hline & $\begin{array}{l}\text { Suspended } \\
\text { solids }\end{array}$ & $\mathrm{Na}$ & $\mathrm{NH}_{4}-\mathrm{N}$ & $\mathbf{K}$ & Mg & $\mathrm{Ca}$ & $\mathrm{Cl}$ & $\mathrm{NO}_{3}-\mathrm{N}$ & $\mathrm{PO}_{4}-\mathrm{P}$ & $\mathrm{SO}_{4}-\mathrm{S}$ & $\mathrm{HCO}_{3}-\mathrm{C}$ \\
\hline \multicolumn{12}{|c|}{ Concentration (mg/L) } \\
\hline B & 53.4 & 5.11 & $<0.01$ & 0.80 & 10.8 & 13.2 & 3.18 & $<0.01$ & $<0.01$ & 4.07 & 17.3 \\
\hline C & 64.8 & 8.7 & 0.08 & 0.90 & 16.0 & 21.4 & 3.77 & 0.01 & $<0.01$ & 8.05 & 22.9 \\
\hline G & 69.4 & 4.84 & 0.12 & 0.68 & 25.1 & 22.8 & 2.77 & 0.02 & $<0.01$ & 2.17 & 38.9 \\
\hline \multicolumn{12}{|c|}{ Flux (kg/ha/year) } \\
\hline B & 96.4 & 9.23 & $<0.01$ & 1.44 & 19.5 & 23.9 & 5.74 & $<0.01$ & $<0.01$ & 7.35 & 31.2 \\
\hline C & 75.7 & 10.2 & 0.09 & 1.05 & 18.7 & 25.0 & 4.4 & 0.01 & $<0.01$ & 9.41 & 26.8 \\
\hline G & 97.2 & 6.78 & 0.17 & 0.95 & 35.1 & 32.0 & 3.87 & 0.03 & $<0.01$ & 3.05 & 54.4 \\
\hline
\end{tabular}

